\title{
Ethical Implication in the Government Governance Reform
}

\author{
Zhou Guowen $^{1}$, Li Shuangshuang ${ }^{2}$ \\ ${ }^{1,2}$ School of Humanities and Social Sciences, Beijing Forestry University, \\ Beijing,,P.R.China, 100083 \\ (E-mail: guowenzhou@126.com, kety-163@163.com)
}

\begin{abstract}
Since the inception of the Public Administration, each reform of governance theory and practice implies enormous ethical values and cares, and every ethical value change will pave the way for government governance reform. The governance modes are closely related to ethical values. The ethical values change will promote the transformation of governance and vice versa. In this paper, with the studies of history and literature, the ethical implication in the government reform theory were analysised and the dialectical relationship between governance change and ethical spirit were presented. We also summed up that the theory of the new public service is the best government governance mode as it contains the most profound ethical values in history. Cultivation of the awareness of ethical responsibility, establishment of the faith of the public interest and public services, safeguard social fairness and justice, the strengthening of civic democratic participation, and the persistence of rule of law are all the shaping the conditions for Public Service ethics.
\end{abstract}

Keywords: Government Governance' Public Administration' Public Management' Public Services; Ethics Implication

\section{Introduction}

Government governance reform is the call of The Times. Under a important government governance Service historical background, The New Public Service Ethics is a modern democratic political adaptability, it is one of the good governance and the rights of a basis points, and believe it for the moral emotions rule based construction government, it is also the root of the modern country. As William. Kymlicka said: "of course, if too many people give up public reason and citizens etiquette, it would rock of system of democracy and stability of the legitimacy foundation. As long as we have from the reason to care the stability of the democratic system, we will all have from the reason to care in the moral character of the overall social citizens level."[1] As the government has public power and represent the public Interests, and ethics parallel with Public Administration closely in the time. The government governance requirements the ethical control, meanwhile, ethical values and spirit guide the government governance reform and innovation. Since Public Administration produced, the Administrative Ethics standards and ethical value of the research is never interrupted. From the Traditional Public Administrative Ethics to the current Public Service Ethics, Ethics promoted the development of Public Administration, but also Public Administration promoted the progress of Ethics.

The Traditional Public Administration Theory as efficiency and hierarchical system as the highest goal, the administrative people without any independent control. With the "impersonal" management way, The Traditional Public Administration ignored social justice, and caused a serious social problem. The New Public Administration Theory is based on The Traditional Public Administration, but it emphasizes ethical values of democracy and justice, and pay attention to the political and administrative influence $r$, and to the study of human nature. Because The New Public Administration is still the continuation of Traditional Public administrative system, the theory and the practice of lack of complicity, and failed to replace the Traditional Public Administration. The New Public Management Theory is based on the enterprise management and economics theory, and taking the market as the guidance, advocating competition, freedom and regard customer as the centre of the concepts of value. 
The New Public Management adapt in today's society in the term of the administrative power decentralized, organization of the flat is adaptable to the trend, the government management reform in play a good role, and bring some economic value. However, the New Public Management executes an enterprise management mode to the government, in order to improve the efficiency as the ultimate goal, destroyed the existing public system, weaken the government responsibility, cause blind competition, the waste of resources, etc.

The New Public Service Theory is a new set of government governance theory and mode, it advocates the creation of a citizen management system, special emphasis on service citizens and protecting the public interests; pay attention to social trust to maintain the public interest ethics, etc. The New Public Service mode is a civil society oriented mode, and the citizen society is towards human universal significance ethical value of democracy, justice, and freedom. Therefore, the New Public Service mode is the most suitable to the social development and progress. Through the training ethical responsibility consciousness, setting up the public interests and public service of belief, safeguard social fairness and justice, and strengthen the citizens, and adhere to the democratic participation law can shape the Public Services Ethics and can make the necessary matting for governance reform.

The innovation of this paper lies in through the Traditional Public Administration from the Public Service to research government governance reform with the ethics, this essay proof the ethical value and government governance reform have the closely relationship, and concludes that the New Public Service is the most ethical value the government Management mode in the human history, and finally giving some suggestion of shaping the New Public Service Ethics.

\section{2 . The Traditional Public Administration Theory}

The Traditional Public Administration from the political-administrative dichotomy in Wilson, Weber's bureaucracy and Taylor's scientific Management of these three theories. The Traditional Public Administration to adopt a "bureaucratic system model" in the organizational structure and efficiency as the sole criterion for evaluation of administrative performance, administrations do not have any independent control over the "impersonal" management approach.

\subsection{A Traditional Public Administration Ethics - Responsibility}

The Traditional Public Administration ethics stressed the ethical responsibility of administration, the representative of the United States, the Cooper. In his book: Administrative Ethics: the administrative responsibility of the way, Cooper believes that the essence of administrative ethical dilemmas is the characteristics of the conflict of roles and responsibilities of the administrative staff, advocates from the administrative staff and administrative organizations to build strengthen the administrative staff of professional ethics and the construction of the administrative system of ethics. [2]

\subsection{The Defect of The Traditional Public Administration Ethics - Emphasis on Efficiency to the Neglect of the Value}

Due to the impact of the hierarchical structure of the bureaucracy and the relationship with citizens, the Traditional Public Administration characteristics of an isolated itself as a technological field. In the areas of action, showing a strong ethical responsibility and moral consciousness. However, this ethical responsibility is not pointing to the citizens, but point to the direct superiors within the organization. The value attributable to efficiency as the highest goal, while ignoring human nature moral and ethical values.

The Traditional Public Administration have not a strong sense of citizen participation in the era of, the interests of the transverse contact structure network is not very complicated, so take accountability in the bureaucracy, strengthen the power of administrative agencies can coordinate a variety of interests the. However, with the development of society and the advancement of technology, the neglect of the value factors and people's initiative and ethical values led to The Traditional Public Administration can not meet the new environment, The New Public Administration paradigm began to rise.

\section{The New Public Administration Theory}

The New Public Administration came from Simon Management behavior and Dahl Public 
administration of the three questions of the two.

\subsection{A New Public Administration Ethics - Emphasis on Democracy and Fairness}

Simon as the representative of The New Public Administration, he seeks to remedy the rational concept of an innovation instrumental rationality concept of Wilson - Weber's bureaucratic system, and more attention to the value factor in the process of The Public Administration, through the coordination of all appropriate means to achieve the purpose. Compared to Traditional Public Administration, New Public Administration as the democratic and fair for the government's target, emphasis on the interaction of politics and administration, focusing on human nature, and administrative ethics research.

\subsection{The Two Defects of The New Public Administration - Theory and Practice Lack Implicated}

The New Public Administration inherited The Traditional Public Administration point of view, the administrative staff is also a rational self-interest, the pursuit of individual utility maximization, "economic man". So, they always seek the greatest possible benefits and the least possible cost and people are basically self-serving, caring and tools.

The New Public Administration still exists in the old administrative system---the hierarchical, over-reliance on rules and discipline, dependent on the leader's authority and responsibility to point to the internalization of the monopoly on the provision of public goods and services, these factor making The New Public Administration cannot rise to practical action, eventually cannot replace the Traditional Public Administration, and promote the birth of the Public Administration.

\section{The New Public Management Theory}

The New Public Management Theory from the economics of public choice theory, principal-agent theory, transaction cost theory and governance theory. The New Public Management Theory advocated market deregulation and private sector management, privatization of state-owned enterprises optimize the ways and means of government management function; the implementation of market-oriented management, as the public as customers, stressed competition to improve government performance; implementation of indulgence government internal management regulatory system to reform the civil service, that should lift the management of regulation and separation of powers to make management process more rationalization; according to the business philosophy of free market competition, private sector management concepts and techniques presented to the customer-oriented, increase efficiency and improve service to reshape the government's image. [3]

\subsection{A New Public Management Ethics -Professional Ethics and Values-Neutral}

First, The New Public Management to dilute the level of authority, and move towards the respect for equal human dignity. all the personnel in the administrative bodies can have their own ethical autonomy, and the sense of moral self-discipline, the basis of the formation of responsibility. This sense of responsibility not just point to a higher level, and to point to the right they are engaged in the spirit of responsibility for public affairs. Second, The New Public Management focused on market-driven mechanism to run public project, which requires executives to develop the ability to maximize the public interest and sensitivity, coupled with the performance evaluation of executives focused on outputs and outcomes, they are able to cultivate persons responsible for the hard work, prudence and moral qualities. Finally, as citizens for the customer, makes the citizens to be able to be directly involved in Public affairs assumed by the Government to increase citizen participation in public affairs and to achieve the citizens' right to information on public projects, which helps to cultivate the moral of the administrative justice quality. [4]

\subsection{The Defect of the New Public}

\section{Management - the Pursuit of Freedom and Competition to the Detriment of Social Equity, Justice}

To a certain extent ,The New Public Management Theory in line with the objective requirements of government reform, however, the New Public Management principles of economics as a theoretical basis, the "economic man" assumptions inevitably lead to the individual seeking to maximize their own interests while ignoring the importance of public interest, ignoring the value factor, contrary to the ultimate goal and purpose. Second, market-oriented and enterprise 
management orientation in The New Public Management Theory is easy to cause the Government to abandon its social functions and to reduce its responsibility, and thus contrary to the purpose of government. "Public" is the core of government governance, copy the private sector management to neglect of its public role, leading to lack of equity, justice, sense of responsibility, moral and ethical concepts. Finally, customer-oriented tend to distort the relationship between government and citizens. Under the social contract, the government's power comes from the authorization of the citizens, the Government should have services for citizens, Public is the government's "owner" rather than customers.

Form The Traditional Public Administration to The new Public Management have something in common: they all as the efficiency of the administrative as the benchmark for the design of Public Administration objectives., and no real thinking of the ethical values of the Public Administration what's more, the Government's role is always above the citizens, likely to cause the "official" position, abuse of power, ethics imbalances. The government's "Public" is not conduct a comprehensive understanding and the social equity, justice and are not really to be achieved, which promote research and development of Public Service ethics.

\section{The New Public Service theory}

Denhardt's New Public Service: the service is not at the helm :the publication of the governance model of public service generally recognized by the industry. Denhardt reflection and criticism on the basis of The Traditional Public Administration, especially The New Public Management, comparative analysis of seven systematic exposition of the basic theoretical connotation of The New Public Service: first, to serve citizens, rather than service to the customer. Second, the pursuit of public interest. Third, the emphasis on civil rights than the emphasis on entrepreneurship. Think of strategic action to be democratic. Fifth, the admission of liability is not simple. Sixth, services, and not at the helm. Seventh, the emphasis on people, not just the emphasis on productivity. [5]

\subsection{A New Public Service Ethics -Civil Society-Oriented, Real Democracy, Fairness and Freedom}

The New Public Service theory is the institutionalized realization of civil rights. The institutionalization of the rights of citizens is a measure of whether a society of justice standard. In other words, it is necessary to form a solid awareness, but only the last employer of the true masters of the citizens is the government, government officials society. Moreover, the mission of The New Public Service is to provide public services. public sector stimulate the enthusiasm of individual citizens or other organizations involved in public service. The New Public Service Ethics can best play the best side of human nature. The New Public Service Ethics allow citizens to feel that the public interest $\mathrm{s}$ of the country's political rights and economic development with citizens share, and expand the horizons of the citizens, to enhance their spiritual level, enabling a variety of ways dedication to serve the public interest. The nature of public services is the foundation of ethical values---the premise of public service value of democracy, equality, citizenship and rights.

\subsection{The Meaning of The New Public Service}

In Theory, the New Public Service source of the theory of democratic citizenship, community and civil society theory, the organization of capitalism and post-modern Public Administration Theory. Democratic citizenship theory emphasizes the essence of existence by the Government to safeguard the legitimate rights of citizens, improve the awareness of political participation of citizens, concerned about the Public interest, thereby enhancing the responsiveness and credibility of the government; community and civil society Theory advocated by the government to actively strengthen community building, promotion of civil society the formation of political participation of citizens to create a good environment; organization humanistic that the Government can not simply efficiency as the goal, executives can not stick to neutral, value and safeguard social fairness and justice; Therefore, the New Public Service is the most ethical spirit of the governance mode in human history and civilization.

In practice, the New Public Service it 
involves people's lives, including compulsory education, public health, health care, social security, public employment, public safety urban and rural residents are most concerned about. It able to provide citizens with a manifestation of the living conditions of human dignity, to enjoy social justice and equality. Second, the essential attribute of The New Public Service is "public", the primary ethical requirements of equality between the members of society, equitable distribution of public goods. public Services through public spending on education, health care, employment, social security, fair starting point, but also to achieve the final result fair to create the conditions. [6]

\subsection{Shape of New Public Service Ethics}

Compared to several old governance model, The New Public Service not only the latest government Management model but also contains the highest ethical values and spirit. The New Public Service originated to people, in order to achieve universal human rights of its value base, further interpretation of the concept to meet the public demand, and all-round development of people as the center of ethical value. Therefore, we must strengthen the training and shaping of the spirit of The New Public Service to make certain bedding to the government governance reform.

\subsubsection{The Development of Ethical}

Responsibility

Responsibility is to construct the key concepts of administrative ethics is the basis of any governance process. Sense of responsibility requirements of the main body of Public Administration, even in the case involves complex value judgments and overlapping specifications in the public interest and serve the citizens. Behavior of Public Administration not only to comply with the law. Democratic norms and other constraints, but also based on authorization citizen, citizen participation and civic sessions based on solving practical problems, to seek the Public interest, in order to achieve the construction of the administrative body of citizenship and sense of responsibility.

5.3.2 To Establish the Faith of the Public Interest and Public Service

Compared with The Traditional Public Administration Theory and Public Management Theory, one of the core principles of The New Public Service is certainly the public interest, and advocate the spirit of public service. Therefore, whether to establish a modern public interest is the touchstone of the test of a qualified administrative staff. Public services faith is the inner motivation to guide the behavior of Public Administration. Faith of the public interest and public service will guide the moral capacity of the administrative staff, a sense of justice and responsibility for the administrative staff to provide a principle of giving priority to Public interest rather than personal interests, in implementing the policy priority, so that the administrative staff's actions are consistent with expectations of the public.

5.3.3 To Safeguard Social Fairness and Justice The New Public Service on the public nature of citizenship, in fact, it is the fair spirit as a public authority of the administrative body in charge of those expectations with an emphasis on. The "Public" nature of Public Administration, the main responsibilities of modern government is to maintain and achieve social equity, justice, Public Administration ought to value the target is also a new concept of public service value proposition. The administrative body in the policy, equal treatment of the legitimate rights and interests of every citizen, recognizing that all citizens have equal rights and equitable distribution of Public goods and Public Services between citizens and administrative behavior and Public policy of equal treatment of different sectors, attention to vulnerable, and uphold justice, not only the result is fair and create equal opportunities.

5.3.4 To Strengthen the Citizens' Democratic Participation

The good order of civil society in Public life in addition to the citizens a strong sense of the rules and abide by the rules of self-discipline, but also inseparable from those of his legitimate interests, behavior, respect for individuality. The New Public Service, citizenship spirit lifted, indicates that the Government and administrative officers respect the rights of citizens, the ideology of Public authority to legitimate lifestyle, personality needs, respect and tolerance. Therefore, The New Public Service, called thinking to strategic action to be democratic. Citizen participation in social and Public governance, the formation of the positive interaction of citizens and government, not only can achieve high performance in Public governance, but also contribute to the formation of the dignity 
of citizens, a sense of belonging and care about him and charitable character, develop good citizenship.

5.3.5 Adhere to the Spirit of the Rule of Law While The New Public Service to highlight the administrative body to achieve the public value of moral responsibility, but it also emphasized the rule of law in the Public Service. No rule of law, it is difficult to ensure effective delivery of public service, and no way to ensure that the public Administration to make the behavior of the Public interest, lost inspected in accordance with the responsibilities of government and its administrative staff behavior. Public power is a coercive power, with relative independence and unary nature, in the exercise of the process there will be structural characteristics of natural corruption. If the opportunity cost of sacrificing the Public interest because the mechanism is not perfect and can almost be ignored, Public administrators can easily drill system gaps and overstepping the law for personal gain, and therefore must adhere to the rule of law in the New concept of Public Service. Of course, this does not mean the exclusion of the rule of virtue. Discretion and legal vacancies that ethics play a role in the vast space, the rule of law and rule by virtue organically combined. [7]

The political democratization promote the formation of The New Public Service Ethics, restore community and the citizen equal authority, to overcome because Public will caused by the lack of moral vacuum dilemma, and realize the "moral consensus" contemporary reconstruction. After all, The New Public Service Ethics is not an abstract concept being, but with the political democratization of the whole social background closely linked. The political democratization promote social structure change, rebuild public service ethics. So it also must use ethics and life community to promote the inner relationship between. Of course, we are not in favor of the political community formulated by the state ideology of religion and government to delimit the public service in advance moral ethics moral bottom line, and through the country strong institutions around to public service of the ethics of moral choice. Because "the government for individual citizens is wrong the designated moral, not because of what life in the way satisfactory, what way of life is not satisfactory, or some other aspects are morally wrong, does not exist established fact. If no moral error this kind of thing, the government imposed moral choice also is not wrong." [8] A moderate moral subjectivity appeared not only help to better safeguard Public Service ethics, and in the can prevent incarnation of the ethics of Public Service moral objectivity become government Management of citizens across an excuse.

\section{Conclusion}

The Traditional Public Administration as bureaucracy for it organizational systems, as efficiency for the goal, ignoring the ethical value and people's initiative factors. This government adapted the social relationships which are not complicated and have achieved good effect in that stage. However, with the development of society and technological advance, Traditional Public Administration can not adapt the new environment, The New Public Administration began to rise. The New Public Administration as a democratic and fair for the government's objectives, and emphasis on the interaction of political and attention to human and administrative ethics, However, The New Public Administration is still using the Traditional system, therefore, it is proposed Theory and did not rise into practical action, eventually failed to replace The Traditional Public Administration, and promote the birth of the New Public Management. The New Public Management to dilute the level of authority, and move towards the respect for equal human dignity; oriented to the market and competition mechanisms to promote the administrative responsibility of the hard-working, prudent and moral qualities; increase citizen participation in public affairs, the realization of civil right to know of Public projects, training of administrative justice, moral and ethical values. Compared to The Traditional Public Administration and The New Public Administration, The New Public Management has progressed. However, The Traditional Public Administration and The New Public Management have something in common, that it the idea of thinking the efficiency as a benchmark in the design of Public Administration and ignore the real ethical values. In addition, the Government's role is always positioned above the citizens, likely to cause the official position, abuse of power, ethics imbalances. The government did not conduct a comprehensive understanding of 
"Public", and shaping of social equity, justice and not really to be achieved, all of these promote research and development of The Public Service Ethics. Compared to the old governance model, the New Public Service is not only the latest government governance model but also contains the highest ethical values and spirit. The New Public Service originated in the care of people, in order to achieve universal human rights of its value base, further interpretation of the concept to meet the public demand, as the healthy living and all-round development of people as the center of ethical value orientation. So, government must cultivate the ethical responsibility of the new public services, and establish the faith of the public interest and public services, safeguard social fairness and justice, strengthening the citizens' democratic participation and uphold the rule of law and other methods to strengthen the construction of new public service ethical values, and these will eventually contribute to the government reform.

\section{References}

[1] [ Canada ] Will Kymlicka: "Contemporary political philosophy "(Second), Liu Xin translates, Shanghai SDX Joint Publishing Company, 2004, page 562. (In Chinese

[2]Terry L. libraries shoot (U.S.), Professor Zhang Translation: "administrative ethics: the administrative responsibility of the way" (M), China Renmin University Press, 2001, Fourth Edition; （In Chinese )

[3] [4]Zhanshi You: "justice and a Public instrument: A Theory of Justice, as the domain of Public ethics, the People's Publishing House, 2006, the first edition; (In Chinese)

[5] [U.S.], Janet V Denhardt, Robert B. Denhardt. "New Public Service rather than at the helm" [M], Renmin University of China Press, 2004; （In Chinese )

[6] Xu Xia: the ethical dimension of Public Service, Northwest Normal University, a master's degree thesis in 2010, 05; (In Chinese)

[7] Wu Yuliang: the ethical values of Public Administration under the New Public Service angle, 'Journal, 2 March 2008; (In Chinese)
[8] [ US ] Hillary Putnam : "Reasonableness, the truth and history ", Tong shiJun and Li GuangCheng translate, Shanghai translation publishing House, 2005, page 168. (In Chinese) 